Creative commons User License: CC BY-NC-ND

Abstracted by: EBSCOhost, Electronic Journals Service (EJS),

Google Scholar, Directory of Open Access Journals (DOAJ),

Journal Seek, Scientific Commons,

Food and Agricultural Organization (FAO), CABI and Scopus
Journal of Agricultural Extension

Vol. 20 (2) December, 2016

ISSN(e): 24086851; ISSN(Print); 1119944X

http://journal.aesonnigeria.org

http://www.ajol.info/index.php/jae

Email: editorinchief@aesonnigeria.org

\title{
Capability of Poultry Farmers Association for Extension Services Delivery in Oyo State, Nigeria \\ http://dx.doi.org/10.4314/jae.v21i1.8
}

\section{Owolade, Esther O.}

Department of Agricultural Extension and Management.

Federal College of animal Health and Production Technology, IAR\&T P.M.B 5029,

Moor Plantation Ibadan, Nigeria

Email: Funmilayoowolade@gmail.com or Ofowolade@gmail.com

Phone: 08038014153

\section{Adebisi, Ganiyu L.}

Department of Agricultural Extension and Management.

Federal College of animal Health and Production Technology, IAR\&T P.M.B 5029,

Moor Plantation Ibadan, Nigeria

Email: debisigbadebo2014@gmail.com; Phone: 08067093595

\section{Alonge, Grace 0.}

Department of Agricultural Extension and Management.

Federal College of animal Health and Production Technology, IAR\&T P.M.B 5029,

Moor Plantation Ibadan, Nigeria

Email: mogalabi@skannet.com; Phone: 08054106354

\section{Adamu, Comfort 0.}

Department of Agricultural Extension and Rural Development.

Federal University of Agriculture, Abeokuta, Ogun State, Nigeria.

Email: comlare2004@yahoo.com; Phone: 08033020406

\section{Lawal-Adebowale Okanlade A.}

Department of Agricultural Extension and Rural Development.

Federal University of Agriculture, Abeokuta, Ogun State, Nigeria.

Email: deboakals@yahoo.com;Phone: 08034893606

\section{Abstract}

The study investigated the capability of Poultry Association of Nigeria (PAN) for extension service delivery to poultry farmers in Oyo state. The respondents were predominantly registered poultry farmers in Oyo state PAN. Questionnaires were administered to 118 registered poultry farmers with PAN. Data were analyzed using percentage, frequency and chi-square at $P=0.05$. Results revealed that most of the respondents were male (64.4\%), within the age bracket of 41-50 years, mostly married (61.9\%), and had attained tertiary education. The majority accessed information on poultry management techniques and marketing during in-house training (34.7\%), farm visits (44.9\%) and workshop (55.1\%) sponsored by PAN. It concluded that the Poultry Association of Nigeria (PAN) Oyo state, chapter has the optimum human and material resources for extension services delivery to its members. The number of trainings and farm visits organized by the association could be improved upon if PAN accesses other sources of funding.

Key Words: Poultry farmers' association; Extension services delivery. 
Creative commons User License: CC BY-NC-ND

Abstracted by: EBSCOhost, Electronic Journals Service (EJS),

Google Scholar, Directory of Open Access Journals (DOAJ),

Journal Seek, Scientific Commons,

Food and Agricultural Organization (FAO), CABI and Scopus
Journal of Agricultural Extension

Vol. 20 (2) December, 2016

ISSN(e): 24086851; ISSN(Print); 1119944X

http://journal.aesonnigeria.org

http://www.ajol.info/index.php/jae

Email: editorinchief@aesonnigeria.org

\section{Introduction}

Poultry is a term used to describe any type of domesticated birds kept for meat and eggs production such as fowls, ducks, geese, turkey, guinea fowls and pigeons (Oluyemi and Roberts, 2007). Poultry is a unique animal species that is recently been considered especially after the Second World War to meet up with the ever increasing need in animal protein in the daily human diet.

The term poultry means those blooded animals with their forelimbs adapted for flying, covered with feathers and reproduce through eggs laying for external incubation and hatching (Oluwadare, 2011). Any birds reared or hunted for useful purpose such as meat and egg production is collectively known as poultry (Oluyemi and Robert, 2007). The term poultry encompass any domesticated fowl raised for its meat and eggs.

Poultry farming in Nigeria has become one of the most important aspects of farming for many reasons. It creates business opportunity for entrepreneurs and provides employment. The population of Nigeria's poultry is about 150.682 million, out of which $25 \%$ are commercially farmed, $15 \%$ semi-commercially and $60 \%$ in backyards or small scale (Onwualu, 2011). This shows that small scale poultry producers are responsible for the bulk of poultry production in Nigeria. Idachaba (2004) advocated a focus on small-scale farmers on the premises that policies targeting these farmers are likely to have a far-reaching impact on increased food production and income. Farmers' organization provides a forum where small scale holders discuss common problems, pool efforts to promote peasants' welfare (International Federation of Agricultural Producers (IFAP), 1992).

Poultry Association of Nigeria (PAN) was founded as one of the agricultural commodity association in Nigerian. The objectives were to establish an association for persons and organizations concerned with an interest in poultry farming, to foster, expand production and improve the efficiency of poultry farming and industry, provide information to its members and public in general on matters pertaining to poultry by such means as publication, conference, seminar, workshops and 
Creative commons User License: CC BY-NC-ND

Abstracted by: EBSCOhost, Electronic Journals Service (EJS),

Google Scholar, Directory of Open Access Journals (DOAJ),

Journal Seek, Scientific Commons,

Food and Agricultural Organization (FAO), CABI and Scopus
Journal of Agricultural Extension

Vol. 20 (2) December, 2016

ISSN(e): 24086851; ISSN(Print); 1119944X

http://journal.aesonnigeria.org

http://www.ajol.info/index.php/jae

Email: editorinchief@aesonnigeria.org

exhibitions, provide facilities and engage in the study of any enquiry and research into poultry farming and publish the outcome through the appropriate media, monitor all legislative, administrative and fiscal measures: give members and employee all such assistance as is possible and desirable, establish and promote training courses, scholarship, grants, awards and prices to encourage education in poultry sciences, farming and management. (Ayanda, et al.2011)

Agricultural extension is a general term meaning the application of scientific research and new knowledge to agricultural practices through farmer education. The field of 'extension' now encompasses a wider range of communication and learning activities organized for rural people by educators from different discipline, including agriculture, agricultural marketing health and business studies.

Extension is designed to help people satisfy their needs, interests, desires and basically to solve problems. Extension as the means by which farmers receive information and technologies is important for improving agricultural productivity and efficiency. Van den Ban and Hawkins (1996) stated that the major role of agricultural extension in many countries in the past was seen to be transfer of new technologies from researchers to farmers. Now it is seen more as a process of helping farmers to make their own decisions by providing them a range of options in a given innovation from which they can choose and by helping the farmers to develop insight into the consequences of each option.

\section{Objectives of the Study}

The objectives of the study were to:

i. determine the socio-economic characteristics of poultry farmers in Oyo State;

ii. describe the type of poultry enterprise in the state;

iii. $\quad$ identify the reasons for keeping poultry in Oyo State;

iv. determine the materials and human resources available to Poultry Association of Nigeria suitable for extension services delivery in the study area;

v. identify the training and input supply activities performed by Poultry Association of Nigeria in the study area; 
Creative commons User License: CC BY-NC-ND

Abstracted by: EBSCOhost, Electronic Journals Service (EJS),

Google Scholar, Directory of Open Access Journals (DOAJ),

Journal Seek, Scientific Commons,

Food and Agricultural Organization (FAO), CABI and Scopus
Journal of Agricultural Extension

Vol. 20 (2) December, 2016

ISSN(e): 24086851; ISSN(Print); 1119944X

http://journal.aesonnigeria.org

http://www.ajol.info/index.php/jae

Email: editorinchief@aesonnigeria.org

vi. examine the sources of fund for in house training, farm and home visit and workshop by poultry Association of Nigeria; and

vii. investigate the constraints to extension services programme in Oyo state.

\section{Methodology}

\section{The Study Area}

The study area was Oyo state, Nigeria. Oyo state was formed on $3^{\text {rd }}$ February 1976 from the western state. It lies between the latitude $7.0^{\circ} \mathrm{N}$ and $9.3^{\circ} \mathrm{N}$ of the equator and between latitude 2.5E and 5.0E of prime meridian. Oyo state covers land area of 27000 sq kilometer and is made up of thirty-three (33) Local Government Areas. It is divided into four agricultural zones by ADPs namely Ibadan, Ibarapa, Oyo and Saki zone.

The population of this study consists of registered poultry farmers with PAN, Oyo state. Multi stage sampling techniques was used to select the respondent for this study. The first stage involved collection of list of registered farmers from Poultry Association of Nigeria, Oyo state chapter. The second stage involved the use of simple random selection techniques to select 120 from the list of registered poultry farmer from PAN. Data were collected by means of structured interview schedule and analyzed with percentages, frequencies and tables.

The personal characteristics of members of PAN such age was measured in years. Marital status was measured in terms of single, divorced/separated, widowed, and married. Respondents were asked to tick as relevant to them. In the same vein, respondents were asked to state their gender by ticking the appropriate box for male or female. Similarly, respondents were asked to state the highest educational level attained by ticking one out of the alternative levels of education provided in the interview schedule. Available human resources were measured in number terms of respondents with tertiary educational qualification with livestock bias. While material resources were measured in terms of number of available training hall, chairs, chalk board, vehicle, power point device that are available to PAN for training and farm visits. Respondents were provided with various alternative sources of information such as radio, television, extension agents, poultry association, feed millers and to 
Creative commons User License: CC BY-NC-ND

Abstracted by: EBSCOhost, Electronic Journals Service (EJS),

Google Scholar, Directory of Open Access Journals (DOAJ),

Journal Seek, Scientific Commons,

Food and Agricultural Organization (FAO), CABI and Scopus
Journal of Agricultural Extension

Vol. 20 (2) December, 2016

ISSN(e): 24086851; ISSN(Print); 1119944X

http://journal.aesonnigeria.org

http://www.ajol.info/index.php/jae

Email: editorinchief@aesonnigeria.org

tick the channel(s) through which information on production and marketing were accessed. Likewise, respondents were asked to indicate quantity of farm inputs such as maize (bags/kilograms), fertilizers (bags/kilograms), vaccines (vials) et cetera accessed through the efforts of PAN.

\section{Result and Discussion}

\section{Socio-economic Characteristics of Members of PAN}

Table 1 revealed that the majority $(65.0 \%)$ of the respondents were in the age bracket of 41 years and above with an average of 45 years. Similarly, 65.0\% were male while $35.0 \%$ were females. People in this age group of 41-50 years are known to be in their active and productive ages. The majority of the respondent were mostly married $(61.9 \%)$. This may have positive effects on the availability of family labor. The majority of the members of poultry association of Nigeria (PAN) had attained tertiary education (89.9\%). This can have a positive effect on the adoption of new recommended practices on poultry production.

Table 1: Socio economic characteristic of members of PAN

\begin{tabular}{ll}
\hline Variety & Percentage \\
\hline Sex & 65.0 \\
Male & 35.0 \\
Female & 18.6 \\
Age & \\
$<30$ & 23.7 \\
$31-40$ & 33.1 \\
$41-50$ & 11.0 \\
$51-60$ & 13.5 \\
$>60$ & \\
Marital status & 27.1 \\
Single & 61.9 \\
Married & 11.0 \\
Widow & \\
Educational Level & 2.5 \\
No formal education & 2.5 \\
Adult education & 0.8 \\
Primary education & 4.2 \\
Secondary education & 89.9 \\
Tertiary education &
\end{tabular}

Source: field survey, 2015 
Creative commons User License: CC BY-NC-ND

Abstracted by: EBSCOhost, Electronic Journals Service (EJS),

Google Scholar, Directory of Open Access Journals (DOAJ),

Journal Seek, Scientific Commons,

Food and Agricultural Organization (FAO), CABI and Scopus
Journal of Agricultural Extension

Vol. 20 (2) December, 2016

ISSN(e): 24086851; ISSN(Print); 1119944X

http://journal.aesonnigeria.org

http://www.ajol.info/index.php/jae

Email: editorinchief@aesonnigeria.org

\section{Types of Poultry Enterprise and Number Possessed}

Table 2 shows that most of the farmers raised broiler (66.1\%) and layers birds $(66.9 \%)$. The majority of the respondent did not raise breeder chicken $(82.2 \%)$, cockerel $(80.5 \%)$, turkey (89\%), and guinea fowl (94.9\%). Most of them raised poultry birds for income generation (82.2\%). Therefore, it was inferred that keeping layers and broilers are more profitable. The biological value of egg is higher and less costly (A600-800 per crate) than animal protein sourced from other livestock species such as goat, cattle and sheep which costs between $\mathrm{A} 800$-N1000 per kilogram.

Table 2: Types of poultry enterprise and reasons for keeping

\begin{tabular}{ll}
\hline Variables & Percentage \\
\hline Broiler & 33.9 \\
Yes & 66.1 \\
No & \\
Commercial Layers & 66.9 \\
Yes & 33.1 \\
No & \\
Breeder chickens & 17.8 \\
Yes & 82.2 \\
No & \\
Cockerel & 19.5 \\
Yes & 80.5 \\
No & \\
Turkey & 11.0 \\
Yes & 89.0 \\
No & \\
Guinea fowl & 5.1 \\
Yes & 94.9 \\
No & \\
Reasons for keeping & 82.2 \\
Income generation & 8.5 \\
Consumption & 1.7 \\
Affection & 7.6 \\
Social Status &
\end{tabular}

Source: field survey, 2015 
Creative commons User License: CC BY-NC-ND

Abstracted by: EBSCOhost, Electronic Journals Service (EJS),

Google Scholar, Directory of Open Access Journals (DOAJ),

Journal Seek, Scientific Commons,

Food and Agricultural Organization (FAO), CABI and Scopus
Journal of Agricultural Extension

Vol. 20 (2) December, 2016

ISSN(e): 24086851; ISSN(Print); 1119944X

http://journal.aesonnigeria.org

http://www.ajol.info/index.php/jae

Email: editorinchief@aesonnigeria.org

\section{Materials, Human Resources Available to PAN and Suitable for Extension Activities}

Table 3 shows that most of respondents were trained on general agriculture $(30.5 \%)$, this is followed by those who were trained animal science (19.5\%) and business administration (14.4\%). It was overt that Poultry Association of Nigeria (PAN) was endowed with human resources capable of performing training functions such as inhouse training and conduct of field trips. These are the conventional functions of the subject matter specialists under the states' Agricultural Development Project (ADPs).

Table 3: Human resources available to PAN for extension services activities in Oyo state.

\begin{tabular}{lc} 
Variables & percentage \\
\hline $\begin{array}{l}\text { Tertiary Education Acquired } \\
\text { General agriculture }\end{array}$ & 30.5 \\
Nursing & 5.1 \\
Engineering & 2.5 \\
Public administration & 3.4 \\
Animal science & 19.5 \\
Business administration & 14.4 \\
Veterinary medicine & 6.8
\end{tabular}

\section{Source: field survey, 2015}

The Poultry Association of Nigeria (PAN) in Oyo state also possessed 120 armed chairs, two (2) power point projectors, ten (10) training halls located in different zones and one (1) vehicle (Table 3.1). These are essentials for conduct of successful in-house trainings and farm visits to members and other poultry farmers in Oyo State. Members of PAN can serve effectively as contact farmers to other nonmembers of PAN. These facilities can be used to bridge the gap created by inadequate extension agents for technical message delivery to poultry producers. 
Creative commons User License: CC BY-NC-ND

Abstracted by: EBSCOhost, Electronic Journals Service (EJS),

Google Scholar, Directory of Open Access Journals (DOAJ),

Journal Seek, Scientific Commons,

Food and Agricultural Organization (FAO), CABI and Scopus
Journal of Agricultural Extension

Vol. 20 (2) December, 2016

ISSN(e): 24086851; ISSN(Print); 1119944X

http://journal.aesonnigeria.org

http://www.ajol.info/index.php/jae

Email: editorinchief@aesonnigeria.org

Table 3.1: Infrastructures and materials available to PAN for extension services activities in Oyo state.

\begin{tabular}{ll}
\hline Infrastructure & Number \\
\hline Existing Branches (chapters) & 10 \\
of PAN in Oyo State & \\
Materials: & \\
Training hall & 10 \\
Power point device & 2 \\
Chairs & 120 \\
Vehicle & 1 \\
\hline
\end{tabular}

Source: field survey, 2015

\section{Training and Input Supply Activities Performed by PAN}

Table 4 shows the training and inputs supply activities performed by PAN. The results show that maize is the highest-ranked input supply by PAN, while fertilizer is the next ranked. The findings agree with that of Collinson (1987) that producer organization assist members to secure inputs, credits et cetera. It is also an indication that PAN is capable of delivering similar services to its members with minimal support from the government. The result also revealed that PAN is capable of supplying pesticides and vaccination to their members, capable of performing inhouse training, providing credit facilities and organizing workshop to the farmers that will benefit the members. Rapidly advancing poultry production technology requires continuing education of producers. 
Creative commons User License: CC BY-NC-ND

Abstracted by: EBSCOhost, Electronic Journals Service (EJS),

Google Scholar, Directory of Open Access Journals (DOAJ),

Journal Seek, Scientific Commons,

Food and Agricultural Organization (FAO), CABI and Scopus
Journal of Agricultural Extension

Vol. 20 (2) December, 2016

ISSN(e): 24086851; ISSN(Print); 1119944X

http://journal.aesonnigeria.org

http://www.ajol.info/index.php/jae

Email: editorinchief@aesonnigeria.org

\section{Table 4: Training and input supply activities performed by PAN}

Extension Activity

Maize

Fertilizer

Pesticide

Vaccination

Credit facility

Farm visit

In house training

Workshop

Source: Field survey, 2015
Mean

3.0250

Rank

$1 s t$

2nd

$3 r d$

4th

6 th

7th

5th

7th

\section{Sources of Information on Production Techniques and Marketing Services}

The majority (65.3\%) of PAN members in Oyo state became aware of recommended poultry productions practices through fellow farmers while $62.7 \%$ are aware of marketing services through the poultry association (Table 5). It was also revealed that $(53.4 \%)$ and $(33.9 \%)$ of respondents that acquired information through radio and extension agents respectively. A small proportion (23.7\%) of respondents received production recommendation from family friends. It was also shown that $31.4 \%$ and 28.8\% accessed information on marketing services through feed millers and extension agents respectively. This confirms the finding of Agbamu (2005) that there are inadequate extension agents to cover large population of farmers in all the subsectors of agriculture in Nigeria. 
Creative commons User License: CC BY-NC-ND

Abstracted by: EBSCOhost, Electronic Journals Service (EJS),

Google Scholar, Directory of Open Access Journals (DOAJ),

Journal Seek, Scientific Commons,

Food and Agricultural Organization (FAO), CABI and Scopus
Journal of Agricultural Extension

Vol. 20 (2) December, 2016

ISSN(e): 24086851; ISSN(Print); 1119944X

http://journal.aesonnigeria.org

http://www.ajol.info/index.php/jae

Email: editorinchief@aesonnigeria.org

Table 5: Sources of information on production techniques and marketing services by the respondent

\begin{tabular}{lcc}
\hline Sources of information & Production techniques & Marketing services \\
\hline & Yes & Yes \\
Radio & 53.4 & 53.4 \\
Television & 27.9 & 38.1 \\
Extension agent & 33.9 & 28.8 \\
Family friends & 23.7 & 28.8 \\
Poultry association & 66.1 & 62.7 \\
Feed millers & 33.1 & 31.4 \\
Poultry marketers & 30.5 & 50.0 \\
Fellow farmers & 65.3 & 45.8 \\
\hline
\end{tabular}

Source: Field survey, 2015

\section{Constraints to Extension Services of PAN}

Table 6 revealed that the major constraint was inadequate funding, followed by inadequate training material and poor vehicular transport owned by PAN were insufficient while insufficient subject matter specialist was perceived as minor constraints by the majority of the respondent. Inadequate funding explained inadequate coverage of members during farm visits by volunteered subject matter specialists within the rank of the association. Thus, critical areas of support by the government or other donors would be transport and funding. Therefore, if the commodity associations such as PAN are focused, extension services will improve with minimal contribution of overheads (vehicle, training facilities) from the governments. 
Creative commons User License: CC BY-NC-ND

Abstracted by: EBSCOhost, Electronic Journals Service (EJS),

Google Scholar, Directory of Open Access Journals (DOAJ),

Journal Seek, Scientific Commons,

Food and Agricultural Organization (FAO), CABI and Scopus
Journal of Agricultural Extension

Vol. 20 (2) December, 2016

ISSN(e): 24086851; ISSN(Print); 1119944X

http://journal.aesonnigeria.org

http://www.ajol.info/index.php/jae

Email: editorinchief@aesonnigeria.org

Table 6: Constraints to extension services of PAN

\begin{tabular}{lrr}
\hline Constraints & Mean & Rank \\
\hline Funding is a limiting factor & 1.91 & $1^{\text {st }}$ \\
Subject matter specialists & 1.48 & $4^{\text {th }}$ \\
were insufficient & \\
Training materials were & 1.18 & $2^{\text {nd }}$ \\
inadequate & \\
Poor vehicular transport & 1.18 & $2^{\text {nd }}$ \\
owned by PAN were \\
insufficient
\end{tabular}

Source: field survey, 2015

\section{Conclusion and Recommendations}

From the findings, poultry association of Nigeria (PAN) Oyo state has some resources for extension service delivery to their members but the most constraints faced by the members is funding to practice poultry production. The majority of the respondent source for information on production techniques from their fellow farmers and they get required information on marketing services from the poultry association. There is need for poultry association of Nigeria (PAN) Oyo state to expose their members to different measures of awareness and also form them to various groups within the association in order to assist them to access credit facilities that will enhance their production. It is important for PAN to work in collaboration with Agricultural Development Programme (ADP) or other private extension organization to facilitate the extension service delivery to their members. 
Creative commons User License: CC BY-NC-ND

Abstracted by: EBSCOhost, Electronic Journals Service (EJS), Google Scholar, Directory of Open Access Journals (DOAJ), Journal Seek, Scientific Commons,

Food and Agricultural Organization (FAO), CABI and Scopus
Journal of Agricultural Extension

Vol. 20 (2) December, 2016

ISSN(e): 24086851; ISSN(Print); 1119944X

http://journal.aesonnigeria.org

http://www.ajol.info/index.php/jae

Email: editorinchief@aesonnigeria.org

\section{References}

Agbamu, J. U. (2005): Problems and prospects of agricultural extension service in developing countries in Agricultural Extension in Nigeria S.F. Afolayan (ed) Ilorin AESON, pp.159-169.

Ayanda, I. F., Banmeke, T. O. A. and Ajayi, M. T. (2011): An overview of livestock component under the Research-Extension-Farmers-Input-Linkage-System of extension services in Kwara State, Nigeria. Proceedings of the 16th annual conference of the Animal Science Association of Nigeria (ASAN) held at Kogi State University, Anyigba, Kogi State, $\quad$ Nigeria, 12th -15th September, 2011, pp205.

Collinson, M. (1987). Farming systems research: Procedures for technology development. Experimental Agriculture 23: 365-386.

Idachaba, F. S. (2004): Food Security in Nigeria: Challenge under Democratic Dispensation, ARMTI. Annual Lecture, ARMTL, llorin Kwara State, Nigeria.

International Federation of Agricultural Producers (IFAP) (1992): "Towards Self-supporting Farmers Organizations"; International Federation of Agricultural Producers, Paris, Pp. 45

Oluwadare. O. P. (2011): Practical guides to management of common tropical livestock diseases with livestock management guides and appendixes by Corporate Transaction Limited, Ketu-Lagos, p.392.

Oluyemi J. A and Robert F. A, (2007): Poultry production in Warm Wet Climate by spectrum Books Limited, Ibadan Pp 1-3

Onwualu, P. Z. (2011): Enhancing competiveness of the Nigerian Livestock Sub- sector through value addition on the industry, Paper Presented at the 16thannual conference of the Animal Science Association of Nigeria (ASAN) held at Kogi State University, Anyigba, Kogi State, Nigeria, 12th -15th September, 2011, pp 1.

Van den Ban, A. W. and Hawkins, H. S. (1996). Agricultural extension, Second edition, Blackwell, Oxford. 